\title{
Starch Source Evaluation in Calf Starter: II. Ruminal Parameters, Rumen Development, Nutrient Digestibilities, and Nitrogen Utilization in Holstein Calves
}

\author{
M. A. Khan, ${ }^{\star 1}$ H. J. Lee, ${ }^{\star 2}$ W. S. Lee, ${ }^{\star}$ H. S. Kim, ${ }^{\star}$ S. B. Kim, ${ }^{\star}$ S. B. Park, ${ }^{\star}$ K. S. Baek, ${ }^{\star}$ J. K. Ha,† \\ and Y. J. Choi† \\ *Dairy Cattle Research Division, National Institute of Animal Science, Cheonan, 330-880, Republic of Korea \\ †School of Agricultural Biotechnology, Seoul National University, Seoul, 151-742, Republic of Korea
}

\section{ABSTRACT}

Ruminal parameters, rumen development, nutrient digestibilities, and $\mathrm{N}$ utilization were estimated in Holstein calves fed starch from different sources. Ground corn, ground barley, ground wheat, and crimped oats were used to formulate 4 isostarch (25\% of starter dry matter) pelleted diets. These diets were randomly allocated to calves ( 16 calves per treatment, 8 female and 8 male) and fed ad libitum along with mixed grass hay throughout the experiment. Ruminal contents and blood were sampled at $d 35,50$, and 70 of age to estimate ruminal parameters and plasma $\beta$-hydroxybutyrate, respectively. At d 70, twenty-four male calves (6/treatment) were randomly selected, euthanized, and forestomach weight, papillae length (PL), papillae width (PW), rumen wall thickness (RWT), and papillae concentration were measured. At d 63, twenty-four female calves (6/treatment) were randomly selected and moved to metabolism stalls to estimate total tract apparent nutrient digestibilities and $\mathrm{N}$ utilization. Female calves were given $2 \mathrm{wk}$ for adaptation to experimental facilities and then total collections of feces and urine were made from d 77 to 84 of age. Ruminal $\mathrm{pH}$ at d 35 of age was higher in calves fed corn and oat diets than in those fed barley and wheat diets. Ruminal $\mathrm{pH}$ at $\mathrm{d} 50$ and 70 of age was the lowest in calves on barley diets followed by those on oat and wheat diets and then by those on the corn diet. Ruminal total volatile fatty acid concentrations at d 35 of age were greatest in calves fed corn or wheat diets followed by those fed barley and oat diets. Calves on corn and wheat diets maintained greater ruminal volatile fatty acids concentrations at $\mathrm{d} 50$ and 70 of age. Ruminal ammonia, acetate, propionate, butyrate, and blood $\beta$-hydroxybutyrate concentrations were also

Received May 3, 2007.

Accepted November 26, 2007.

${ }^{1}$ M. A. Khan designed and conducted this study as a part of postdoctoral research.

${ }^{2}$ Corresponding author: ajmals1@yahoo.com greater in calves on the corn and wheat diets. Full and empty weights of forestomach, PL, PW, RWT, and papillae concentrations were greater in calves on corn and wheat diets. Daily average intake of nutrients (dry matter, crude protein, neutral detergent fiber, starch, $\mathrm{Ca}$, and $\mathrm{P}$ ) was greater in calves fed corn and wheat diets than in those fed barley and oat diets. Starch source did not influence the total tract apparent digestibilities of nutrients in calves. Daily $\mathrm{N}$ retention $(\mathrm{g} / \mathrm{d})$ was greatest on the corn diet followed by the wheat diet and then the barley and oat diets. In conclusion, calves on a corn diet have greater ruminal capacity to accommodate feed bulk. More physically and metabolically functional rumens in calves on corn and wheat diets probably resulted in greater feed consumption and $\mathrm{N}$ retention.

Key words: calf starter, rumen development, digestibility, starch

\section{INTRODUCTION}

The process of transitioning calves from their neonatal reliance on nutrients supplied from milk to nutrients supplied from solid feed (cereal grains and hay) is of substantial economic importance to the producer. This transition results in tremendous metabolic ramifications to calf growth rate, because tissues must convert from reliance on glucose supplied from milk to the metabolism of short-chain fatty acids as primary energy substrates (Baldwin et al., 2004). In the preweaned dairy calf, solid feed intake, especially high carbohydrate diets, stimulates rumen microbial proliferation and VFA production, subsequently initiating rumen development (Suárez et al., 2006a).

Normal development of ruminal papillae is the result of microbial fermentation products and physical stimulation of solid feed (Harrison et al., 1960). However, the influence of solid feeds on rumen development may vary, and development of the rumen epithelium, rumen muscularization, and increases in rumen volume have been found to occur independently (Harrison et al., 
1960; Baldwin et al., 2004). Nevertheless, numerous researchers have indicated that ingestion of dry feeds and the resultant microbial end products sufficiently stimulate rumen epithelial development (Stobo et al., 1966). However, the stimulatory effects of different VFA are not equal, with butyrate being most stimulatory followed by propionate (Tamate et al., 1962). The sequence of establishment of the ruminal bacterial population appears to be primarily dependent on the dietary composition of the calf starter (Nocek et al., 1984). Chemical composition of the feeds, and the resultant microbial digestion end products, has the greatest influence on rumen epithelial development, metabolic transition, and performance of dairy calves (Nocek et al., 1984).

Cereal grains are the primary source of starch in ruminant diets. Corn, rice, barley, wheat, oat, and sorghum are commonly used worldwide as starch sources in animal feeds (Huntington, 1997). Physical form of starch and the cellular integrity of starch-containing units affect grain availability to microbes and nutrient digestibility (Philippeau et al., 1999; Theurer et al., 1999). Small grains (wheat, barley, or oats) are more rapidly fermented than corn and sorghum (Huntington, 1997) because the distribution of starch granules within the kernel varies with cereal grain type (Kotarski et al., 1992; Swan et al., 2006). The amylose:amylopectin ratio also varies in cereal grains and was negatively correlated with starch digestion (Svihus et al., 2005). Differences in starch granule size (1 to $38 \mu \mathrm{m}$ ), granule shape (lenticular, polyhedric, or spherical), and interactions between amylose and surface compounds such as fatty acids and protein could alter the rate of enzymatic digestion of corn, barley, oat, and wheat starch (Nocek and Tamminga, 1991; Kotarski et al., 1992; Svihus et al., 2005). These variations may affect the quantity and proportion of VFA in the rumen of neonatal calves and thus ruminal development and nutrient utilization. However, scientific research to evaluate dietary effects of different starch sources in calf starter on feed consumption, growth, metabolic response, rumen development, nutrient digestibilities, and nitrogen utilization in dairy calves is limited. Feed consumption, BW gain, skeletal growth, and selected blood metabolites during preweaning and postweaning periods in Holstein calves fed different starch sources (corn, wheat, oats, and barley) were evaluated and presented in a companion article (Khan et al., 2007a).

This study was conducted to evaluate the effects of starch sources (corn, wheat, oats, and barley) in calf starter on ruminal parameters, rumen development, nutrient digestibilities, and $\mathrm{N}$ utilization in Holstein calves.

\section{MATERIALS AND METHODS}

\section{Calves, Management, Feeding, and Treatments}

Animals, feeding regimens, diets, and general management are described in the companion paper (Khan et al., 2007a) and are summarized below. All experimental procedures were reviewed and approved by the ethics committee on the use of animals in research, National Institute of Animal Science, South Korea.

Holstein calves ( $\mathrm{n}=64,32$ male and 32 female) born between February and May 2006 were separated from their mothers within $2 \mathrm{~h}$ of birth, weighed, and moved into individual pens $(1.5 \times 2.5 \mathrm{~m}$; bedded with wood shavings) where they were fed colostrum at $10 \%$ of BW for the first $3 \mathrm{~d}$. The individual pens were interspersed evenly throughout the calf barn. Pens had solid iron rod sides, with openings in the front and rear to allow calves ad libitum access (10\% refusal) to calf starter and chopped mixed grass hay (MGH) from 2 different feeding buckets. All calves were fed whole milk using mobile plastic bottles (2-L capacity) fitted with soft rubber nipples according to a step-down procedure (Khan et al., 2007b,c).

Ground corn, ground barley, ground wheat, and crimped oat were used to formulate 4 isostarch, isonitrogenous, and isocaloric diets (pelleted calf starters). Oats were crimped because crimping is a commonly used processing method, and the literature (Offner et al., 2003; Svihus et al., 2005) explained similar ruminal disappearance of starch with ground extruded and crimped grains. Ingredients and chemical composition of calf starter diets is presented in Tables 1 and 2, respectively. These calf starters were randomly allocated to calves ( 16 calves per treatment, 8 female and 8 male) and fed ad libitum (10\% refusals) throughout the experiment. Calves were provided free access to water from a bowl drinker in each pen.

\section{Ruminal Contents and Blood Sampling}

At d 35, 50, and 70 of age ruminal contents were collected approximately 3 to $4 \mathrm{~h}$ postfeeding using a stomach tube and a large syringe. Sample $\mathrm{pH}$ was determined immediately using a $\mathrm{pH}$ meter (HM-21P, Toa Corp., Tokyo, Japan). Ruminal contents were squeezed through 4 layers of cheesecloth and rumen fluid (15 $\mathrm{mL}$ ) samples were collected in tubes, placed on ice, and transported to the laboratory where they were acidified with $3 \mathrm{~mL}$ of $25 \%$ metaphosphoric acid and $3 \mathrm{~mL}$ of $0.6 \%$ 2-ethyl butyric acid (internal standard), and stored $\left(-20^{\circ} \mathrm{C}\right)$ until analyzed for VFA and $\mathrm{NH}_{3}$. Samples were later twice centrifuged at $4,500 \times g$ for 30 $\min$ at $4^{\circ} \mathrm{C}$ to obtain a clear supernatant. The supernatant was analyzed for rumen $\mathrm{NH}_{3}$ using a phenolhypo- 
Table 1. Ingredient composition of starter $\operatorname{diets}^{1}$

\begin{tabular}{lcccc}
\hline Ingredient, \% of DM & Barley & Corn & Oat & Wheat \\
\hline Ground barley & 40.00 & - & - & - \\
Ground corn & - & 30.00 & - & - \\
Crimped oats & - & - & 50.00 & - \\
Ground wheat & - & - & - & 40.00 \\
Wheat mill run & 15.00 & 15.00 & 5.00 & 15.00 \\
Rice polish & 1.00 & 2.00 & 2.00 & 2.00 \\
Gluten feed & 4.73 & 13.96 & 2.87 & 1.12 \\
Soybean meal & 9.92 & 15.00 & 8.57 & 13.91 \\
Corn germ meal & - & - & 2.00 & - \\
Corn gluten & 16.67 & 11.93 & 14.47 & 15.06 \\
Soyhulls & - & - & 1.55 & - \\
Milk powder & 6.00 & 6.00 & 6.00 & 6.00 \\
Isolated soy protein & - & - & 1.14 & - \\
Salt & 0.2 & 0.2 & 0.05 & 0.2 \\
Molasses & 1.00 & 1.00 & 1.00 & 1.00 \\
Dicalcium phosphate & 0.10 & 0.10 & 0.30 & 0.30 \\
CaCO 3 & 2.15 & 2.05 & 0.96 & 1.93 \\
MgO (50\%) & 0.13 & 0.13 & 0.06 & 0.13 \\
KCl & 0.14 & 0.07 & 0.4 & 0.4 \\
L-Lysine (78\%) & 0.21 & 0.11 & 1.00 & 0.11 \\
L-Threonine (98\%) & 0.02 & 0.01 & 0.05 & 0.02 \\
Bentonite & 1.41 & 1.12 & 1.26 & 1.50 \\
Neomycin (11\%) & 0.05 & 0.05 & 0.05 & 0.05 \\
Teramycin (OTC 20\%) & 0.05 & 0.05 & 0.05 & 0.05 \\
Vitamin and mineral premix & 1.22 & 1.22 & 1.22 & 1.22 \\
\hline
\end{tabular}

${ }^{1}$ Pelleted starter diets contained equal amount of starch $(25 \%$ of feed DM) from different sources.

chlorite assay (Broderick and Kang, 1980) and molar concentration of VFA by gas chromatography.

Blood samples were taken from the jugular vein at $\mathrm{d} 35,50$, and 70 of age, between 3 to $4 \mathrm{~h}$ after feeding, and collected in heparinized Vacutainers (Becton, Dickinson Co., Franklin Lakes, NJ); plasma was harvested and stored at $-20^{\circ} \mathrm{C}$ until analysis. The BHBA was determined by using an enzymatic method (3-hydroxybutyrate dehydrogenase; Williamson and Mellanby, 1974); BHBA was transformed into acetoacetate by the dehydrogenase enzyme in the presence of NAD. During this reaction, NAD was transformed to reduced nicotinamide adenine dinucleotide. The increase in the amount of reduced nicotinamide adenine dinucleotide was measured at $340 \mathrm{~nm}$ and was proportional to the amount of BHBA. Quantification was done by using a chemical standard solution.

\section{Rumen Weight and Tissue Sampling}

At d 70, twenty-four male calves (6/treatment) were randomly selected and euthanized using captive-bolt stunning and exsanguination. Digestive tracts were harvested, weighed, emptied, and rinsed with cold water, and rumen tissue samples were collected for analysis of papillae length (PL), papillae width (PW), and rumen wall thickness (RWT) according to Lesmeister et al. (2004). Full and empty weights of rumen-reticulum, omasum, and abomasum were measured and papillae concentration was recorded.

\section{Total Collection of Feces and Urine}

At d 63, twenty-four female calves (6/treatment) were randomly selected and moved to metabolism stalls. The BW of calves (at d 63) was $72.55 \pm 2.10,80.60 \pm 3.2$, $75.22 \pm 2.8$, and $78.87 \pm 2.9$ for barley, corn, oat, and wheat diets, respectively. The size $(125 \times 50 \mathrm{~cm})$ of metabolism stalls provided the calf with enough room to stand up and lie down, but restricted any movement back and forth or side to side. The calves were secured with a head stanchion and tied with a rope halter. Calves stood on grates that can allow for the collection of feces and urine. Urine was directed into a plastic bucket via an aluminum funnel, which was located under the back half of the stall. The female calves were offered ad libitum calf starter and MGH using feeding buckets. The calves in metabolism stalls were fed the same diets that they were eating before in individual cages. Polythene sheets were attached around each feeding bucket to account for wastage of calf starter and hay. During the collection period, daily feed intake and refusals for each calf were recorded and sampled for analysis. Calves were provided free access to water from a bowl drinker in each metabolism stall. The calves were given $2 \mathrm{wk}$ for adaptation to experimental facilities and then total collections of feces and urine were made from $d 77$ to 84 .

Collection pans were checked daily at 0730 and 1630 $\mathrm{h}$ to ensure that feces were not contaminated with urine. Feces were collected daily in aluminum pans measuring $41.9 \times 30.5 \times 6.35 \mathrm{~cm}$. Feces for each calf were weighed daily, thoroughly mixed, subsampled, and immediately analyzed for N (AOAC, 1990) without drying to minimize $\mathrm{N}$ loss due to volatilization. A second subsample was dried for $96 \mathrm{~h}$ at $55^{\circ} \mathrm{C}$, composited by calf, ground in a Wiley mill (Arthur H. Thomas, Philadelphia, PA), and then stored in glass containers until laboratory analysis. Feed, refusals, and fecal samples were analyzed for contents of DM, energy, and $\mathrm{N}$ according to the procedures of AOAC (1990), and for NDF (Van Soest et al., 1991) using $\alpha$-amylase (Sigma No. A3306, Sigma Chemical Co., St. Louis, MO) and sodium sulfite and corrected for ash concentration adapted for Ankom 200 Fiber Analyzer (Ankom Technology, Fairport, NY). Starch content of the feeds was determined according to the procedure of Hall (2001). Calcium and $\mathrm{P}$ were measured by inductively coupled plasma emission spectroscopy using an Atom Scan 25 plasma spectrometer (Thermo Jarrell Ash Corp., Grand Junction, CO) after acid digestion. Total tract apparent DM, CP, $\mathrm{NDF}$, starch, $\mathrm{Ca}$, and $\mathrm{P}$ digestibilities were calculated. 
Table 2. Mean ( \pm SE) chemical composition of starters (\% of DM), mixed grass hay (\% of DM), and milk (\%)

\begin{tabular}{|c|c|c|c|c|c|c|}
\hline \multirow[b]{2}{*}{ Parameter } & \multicolumn{4}{|c|}{ Starter $\operatorname{diet}^{1}$} & \multirow[b]{2}{*}{$\mathrm{MGH}^{2}$} & \multirow[b]{2}{*}{ Milk $^{3}$} \\
\hline & Barley & Corn & Oat & Wheat & & \\
\hline $\mathrm{DM}$ & $89.60 \pm 1.22$ & $89.40 \pm 1.43$ & $90.20 \pm 2.11$ & $88.20 \pm 1.51$ & $87.80 \pm 1.70$ & $12.21 \pm 0.21$ \\
\hline $\mathrm{NDF}$ & $15.50 \pm 1.2$ & $15.44 \pm 1.1$ & $20.09 \pm 0.87$ & $13.43 \pm 0.75$ & $65.00 \pm 3.2$ & $\mathrm{ND}^{4}$ \\
\hline $\mathrm{ADF}$ & $5.44 \pm 0.22$ & $5.24 \pm 0.25$ & $8.11 \pm 0.40$ & $3.87 \pm 0.35$ & $37.0 \pm 2.31$ & ND \\
\hline NFC & $41.18 \pm 2.01$ & $38.84 \pm 1.25$ & $36.60 \pm 1.98$ & $41.63 \pm 2.08$ & ND & ND \\
\hline Starch & $25.00 \pm 1.35$ & $25.60 \pm 1.20$ & $24.90 \pm 1.40$ & $25.00 \pm 1.50$ & ND & ND \\
\hline Lactose & ND & ND & ND & ND & ND & $4.77 \pm 0.03$ \\
\hline $\mathrm{Ca}$ & $0.90 \pm 0.01$ & $0.88 \pm 0.05$ & $0.84 \pm 0.02$ & $0.98 \pm 0.01$ & $0.80 \pm 0.02$ & $112 \pm 1.81$ \\
\hline $\mathrm{P}$ & $0.48 \pm 0.05$ & $0.50 \pm 0.06$ & $0.48 \pm 0.04$ & $0.54 \pm 0.05$ & $0.38 \pm 0.05$ & $76 \pm 1.52$ \\
\hline Gross energy, kcal/g of DM & $4.67 \pm 0.12$ & $4.72 \pm 0.20$ & $4.87 \pm 0.25$ & $4.64 \pm 0.20$ & $4.63 \pm 0.30$ & ND \\
\hline
\end{tabular}

${ }^{1}$ Pelleted starter diets contained equal amount of starch (25\% of feed DM) from different sources.

${ }^{2}$ Mixed grass hay contained $43 \%$ orchard grass, $43 \%$ tall fescue, and $14 \%$ white clover on DM basis.

${ }^{3}$ Milk storage tank samples $(\mathrm{n}=20)$.

${ }^{4} \mathrm{ND}=$ not determined.

Urine of each calf was collected daily during collection period in 10-L plastic buckets. Urine was acidified by addition of $90 \mathrm{~mL}$ of $50 \% \mathrm{HCl}$ to the buckets daily to minimize the loss of ammonia. The volume of urine produced by each calf was measured, and $1 \%$ of the volume was saved and combined by calf. The composited urine samples were frozen and stored at $-20^{\circ} \mathrm{C}$ until analyzed for $\mathrm{N}$ by Kjeldahl (AOAC, 1990). Nitrogen balance (retention) was calculated as intake $\mathrm{N}$ fecal $\mathrm{N}$ - urinary $\mathrm{N}$.

\section{Statistical Analysis}

Ruminal parameters and blood BHBA data were analyzed as a randomized complete block design using the GLM procedure of SAS (SAS Institute, 1994). Calves were blocked by the week in which they began the study. Ruminal development parameters, nutrient intake and digestibility, and nitrogen utilization data were analyzed as a completely randomized design using the GLM procedure of SAS (SAS Institute, 1994). The differences in treatment means were tested using Duncan's multiple range test. Significance was declared at $P<0.05$ unless otherwise noted.

\section{RESULTS}

The calves remained healthy and exhibited no sign of distress or illness other than diarrhea during the experiment. Skeletal growth, weekly BW gain, nutrient consumption, blood metabolites, and health parameters during preweaning and postweaning in calves fed starter diets containing starch from different sources are described elsewhere (Khan et al., 2007a). Ruminal contents collected at d 35 were watery in all calves, whereas the contents were pasty and viscous at $d 50$ and 70 of age. The mucosa of all calves fed starch from different sources had a dark brown color.

Ruminal $\mathrm{pH}$ at $\mathrm{d} 35$ of age in calves fed corn and oat diets was higher $(P<0.05)$ than in those fed barley and wheat diets (Table 3). Ruminal pH at d 50 and 70 of age was the lowest $(P<0.03)$ in calves on the barley diet followed by those on oat and wheat diets, and then in those on the corn diet. Ruminal ammonia concentration was increased in all the calves with advancing age (Table 3). Calves on corn and wheat diets maintained greater $(P<0.05)$ ruminal ammonia concentrations than those fed barley and oat diets.

Ruminal total VFA concentration at d 35 of age was the greatest $(P<0.05)$ in calves fed corn or wheat diets followed in those fed barley diet and then in those fed oat diet (Table 4). Ruminal total VFA concentration

Table 3. Average ruminal $\mathrm{pH}$ and ammonia concentrations in Holstein calves fed calf starter diets containing barley $(n=16)$, corn $(n=$ $16)$, oats $(\mathrm{n}=16)$, and wheat $(\mathrm{n}=16)$

\begin{tabular}{lrrrrr}
\hline & \multicolumn{5}{c}{ Diet $^{1}$} \\
\cline { 2 - 5 } Parameter & Barley & Corn & Oat & Wheat & SEM \\
\hline Ruminal pH & & & & & \\
d 35 & $5.23^{\mathrm{b}}$ & $5.49^{\mathrm{a}}$ & $5.41^{\mathrm{a}}$ & $5.19^{\mathrm{b}}$ & 0.12 \\
d 50 & $5.46^{\mathrm{c}}$ & $5.79^{\mathrm{a}}$ & $5.68^{\mathrm{b}}$ & $5.62^{\mathrm{b}}$ & 0.10 \\
d 70 & $5.66^{\mathrm{c}}$ & $6.16^{\mathrm{a}}$ & $5.96^{\mathrm{b}}$ & $5.95^{\mathrm{b}}$ & 0.14 \\
Ruminal ammonia, mmol/L & & & & & \\
d 35 & $5.21^{\mathrm{b}}$ & $6.22^{\mathrm{a}}$ & $5.11^{\mathrm{b}}$ & $6.40^{\mathrm{a}}$ & 0.40 \\
d 50 & $8.55^{\mathrm{b}}$ & $11.99^{\mathrm{a}}$ & $7.49^{\mathrm{b}}$ & $12.40^{\mathrm{a}}$ & 0.65 \\
d 70 & $11.20^{\mathrm{b}}$ & $15.44^{\mathrm{a}}$ & $9.46^{\mathrm{b}}$ & $14.63^{\mathrm{a}}$ & 0.89 \\
\hline
\end{tabular}

${ }^{\mathrm{a}-\mathrm{c}}$ Within rows, means with different superscript letters are significantly different $(P<0.05)$.

${ }^{1}$ Pelleted starter diets containing equal amount of starch $(25 \%$ of feed DM) from barley, corn, oats, and wheat were fed to calves. 
Table 4. Mean ruminal total VFA, acetate, propionate, butyrate and blood BHBA concentrations in Holstein calves fed calf starter diets containing barley $(n=16)$, corn $(n=16)$, oats $(n=16)$, and wheat $(\mathrm{n}=16)$

\begin{tabular}{lccccc}
\hline & \multicolumn{5}{c}{ Diet $^{1}$} \\
\cline { 2 - 4 } $\begin{array}{l}\text { Parameter, } \\
\text { Mmol/L }\end{array}$ & Barley & Corn & Oat & Wheat & SEM \\
\hline Total VFA & & & & & \\
d 35 & $84.09^{\mathrm{b}}$ & $99.40^{\mathrm{a}}$ & $76.16^{\mathrm{c}}$ & $101.68^{\mathrm{a}}$ & 3.51 \\
d 50 & $64.83^{\mathrm{b}}$ & $84.46^{\mathrm{a}}$ & $68.52^{\mathrm{b}}$ & $89.09^{\mathrm{a}}$ & 3.14 \\
d 70 & $88.43^{\mathrm{b}}$ & $111.17^{\mathrm{a}}$ & $90.05^{\mathrm{b}}$ & $118.07^{\mathrm{a}}$ & 4.28 \\
Acetate & & & & & \\
d 35 & $43.55^{\mathrm{b}}$ & $53.94^{\mathrm{a}}$ & $51.6^{\mathrm{a}}$ & $58.07^{\mathrm{a}}$ & 2.22 \\
d 50 & $33.28^{\mathrm{c}}$ & $47.47^{\mathrm{a}}$ & $39.69^{\mathrm{b}}$ & $49.75^{\mathrm{a}}$ & 1.92 \\
d 70 & $47.64^{\mathrm{c}}$ & $58.55^{\mathrm{b}}$ & $46.35^{\mathrm{c}}$ & $66.73^{\mathrm{a}}$ & 3.47 \\
Propionate & & & & & \\
d 35 & $21.40^{\mathrm{a}}$ & $23.34^{\mathrm{a}}$ & $14.31^{\mathrm{b}}$ & $19.73^{\mathrm{a}}$ & 1.21 \\
d 50 & $17.15^{\mathrm{b}}$ & $22.34^{\mathrm{a}}$ & $15.90^{\mathrm{b}}$ & $20.93^{\mathrm{a}}$ & 1.44 \\
d 70 & $21.11^{\mathrm{b}}$ & $30.21^{\mathrm{a}}$ & $23.04^{\mathrm{b}}$ & $31.28^{\mathrm{a}}$ & 2.23 \\
Butyrate & & & & & \\
d 35 & $8.70^{\mathrm{c}}$ & $15.06^{\mathrm{a}}$ & $5.40^{\mathrm{d}}$ & $12.63^{\mathrm{b}}$ & 0.91 \\
d 50 & $6.45^{\mathrm{c}}$ & $10.03^{\mathrm{b}}$ & $7.33^{\mathrm{c}}$ & $13.09^{\mathrm{a}}$ & 0.85 \\
d 70 & $15.53^{\mathrm{b}}$ & $21.08^{\mathrm{a}}$ & $16.04^{\mathrm{b}}$ & $20.23^{\mathrm{a}}$ & 1.01 \\
BHBA, mmol / L & & & & & \\
d 35 & $0.06^{\mathrm{b}}$ & $0.13^{\mathrm{a}}$ & $0.05^{\mathrm{b}}$ & $0.10^{\mathrm{a}}$ & 0.001 \\
d 50 & $0.08^{\mathrm{b}}$ & $0.14^{\mathrm{a}}$ & $0.07^{\mathrm{b}}$ & $0.13^{\mathrm{a}}$ & 0.002 \\
d 70 & $0.10^{\mathrm{b}}$ & $0.19^{\mathrm{a}}$ & $0.11^{\mathrm{b}}$ & $0.17^{\mathrm{a}}$ & 0.005 \\
\hline
\end{tabular}

${ }^{\mathrm{a}-\mathrm{d}}$ Within rows, means with different superscript letters are significantly different $(P<0.05)$.

${ }^{1}$ Pelleted starter diets containing equal amount of starch $(25 \%$ of feed DM) from barley, corn, oats, and wheat were fed to calves.

was decreased at d 50 compared with d 35 of age in all calves. At $d 50$ and 70, the calves on corn and wheat diets exhibited greater $(P<0.05)$ ruminal total VFA concentrations than those fed barley and oat diets.

Ruminal acetate at $d 35$ was greater $(P<0.05)$ in calves fed corn, oat, and wheat diets than in those fed the barley diet (Table 4). At d 50, acetate concentration was the greatest $(P<0.05)$ in calves fed corn and wheat diets followed in those fed the oat diet and then in those fed the barley diet. At d 70 of age, acetate concentration was the greatest $(P<0.05)$ in calves fed the wheat diet followed by those fed corn, barley, and oat diets.

Calves fed barley, corn, and wheat diets had greater ruminal propionate than those fed oat diet at d 35 of age (Table 4). At d 50 and 70 of age, ruminal propionate was greater $(P<0.05)$ in calves fed corn and wheat diets than in those fed barley and oat diets.

Ruminal butyrate concentration at $\mathrm{d} 35$ was the greatest $(P<0.05)$ in calves fed the corn diet followed by those fed wheat, barley, and oat diets (Table 4). At d 50 of age, the calves on the wheat diet exhibited greater ruminal butyrate concentrations than those fed corn, oat, and barley diets. Ruminal butyrate was greater $(P<0.05)$ in calves fed corn and wheat diets than in those fed barley and oat diets at d 70 of age.

Plasma BHBA concentration was greater $(P<0.05)$ at $d 35,50$, and 70 of age in calves fed corn and wheat diets than in those fed barley and oat diets (Table 4).
Full and empty weights of rumen-reticulum, omasum, and abomasums were greater $(P<0.05)$ in calves fed corn and wheat diets than in those fed barley and oat diets (Table 5). Ruminal wall thickness was also greater $(P<0.05)$ in calves fed corn and wheat diets than in those fed barley and oat diets. Ruminal papillae length and PW were the greatest $(P<0.05)$ in calves fed corn starch followed by those fed wheat, barley, and oat starch. Calves on corn and wheat diets had greater $(P<0.05)$ ruminal papillae concentrations than those fed barley and oat diets (Table 5).

Calves on corn and wheat diets consumed more $(P<$ 0.05) DM than those fed barley and oat diets (Table 6). Daily CP, energy, and NDF intakes were the greatest $(P<0.05)$ in calves on the corn diet followed by those fed the wheat diet and then in those fed the oat and barley diets. Calves on corn and wheat diets consumed more $(P<0.05) \mathrm{Ca}$ and $\mathrm{P}$ than those fed barley and oat diets. Starch source did not influence the total tract apparent digestibilities of nutrients (DM, CP, NDF, starch, and Ca) in calves. Phosphorus digestibility was the greatest $(P<0.05)$ in calves fed the corn diet followed by those fed the barley and wheat diets and then by those fed oat starch (Table 6).

Daily $\mathrm{N}$ intake was the greatest $(P<0.05)$ in calves fed the corn diet followed by those fed the wheat, barley, and oat diets (Table 7). Daily fecal N excretion was greater $(P<0.05)$ in calves on the corn and wheat diets than in those fed the barley and oat diets. Daily urinary $\mathrm{N}$ excretion was the greatest $(P<0.05)$ in calves fed the corn diet followed by those fed wheat, barley, and oat diets. Nitrogen balance $(\mathrm{g} / \mathrm{d}$, as a percentage of $\mathrm{N}$ intake) was greatest $(P<0.05)$ in calves fed the corn diet followed by those fed the wheat diet and then in those fed the oat and barley diets. Nitrogen balance (g/ $\mathrm{d}$, as a percentage of digestible $\mathrm{N}$ intake) was greatest $(P<0.05)$ in calves fed either corn or wheat diets followed by those fed oat and barley diets.

\section{DISCUSSION}

Lower ruminal $\mathrm{pH}$ in calves on barley and wheat diets compared with those fed corn and barley diets at d 35 of age may be explained by differences in solid feed intake and starch fermentation pattern. Barley and wheat starch ferment more rapidly than corn and oat starch (Philippeau et al., 1999). Differences in starch granule size, shape (lenticular, polyhedric, or spherical), and interactions between amylose and surface compounds can alter the rate of enzymatic digestion of corn, barley, oat, and wheat starches (Nocek and Tamminga, 1991; Kotarski et al., 1992). Lower solid feed (starter) and starch consumption is generally related to poor ruminal fermentation, VFA buildup, and 
Table 5. Body weights and forestomach measurements of Holstein male calves ${ }^{1}$ fed calf starter diets containing barley $(\mathrm{n}=6)$, corn $(\mathrm{n}=6)$, oats $(\mathrm{n}=6)$, and wheat $(\mathrm{n}=6)$

\begin{tabular}{lccccc}
\hline & \multicolumn{5}{c}{ Diet $^{2}$} \\
\cline { 2 - 5 } Parameter & Barley & Corn & Oat & Wheat & SEM \\
\hline BW, kg & $82.83^{\mathrm{c}}$ & $100.90^{\mathrm{a}}$ & $83.50^{\mathrm{c}}$ & $95.35^{\mathrm{b}}$ & 3.87 \\
Full weight, kg & & & & & \\
$\quad$ Rumen reticulum & $12.05^{\mathrm{b}}$ & $15.35^{\mathrm{a}}$ & $11.40^{\mathrm{b}}$ & $14.59^{\mathrm{a}}$ & 0.92 \\
Omasum & $0.76^{\mathrm{b}}$ & $1.11^{\mathrm{a}}$ & $0.61^{\mathrm{b}}$ & $1.03^{\mathrm{a}}$ & 0.11 \\
Abomasum & $1.50^{\mathrm{b}}$ & $1.95^{\mathrm{a}}$ & $1.35^{\mathrm{b}}$ & $1.82^{\mathrm{a}}$ & 0.12 \\
Empty weight, kg & & & & & \\
Rumen reticulum & $1.28^{\mathrm{b}}$ & $1.53^{\mathrm{a}}$ & $1.21^{\mathrm{b}}$ & $1.45^{\mathrm{a}}$ & 0.09 \\
Omasum & $0.39^{\mathrm{b}}$ & $0.51^{\mathrm{a}}$ & $0.35^{\mathrm{b}}$ & $0.48^{\mathrm{a}}$ & 0.05 \\
Abomasum & $0.40^{\mathrm{b}}$ & $0.54^{\mathrm{a}}$ & $0.36^{\mathrm{b}}$ & $0.47^{\mathrm{a}}$ & 0.04 \\
Ruminal wall thickness, cm & $1.63^{\mathrm{b}}$ & $1.95^{\mathrm{a}}$ & $1.55^{\mathrm{b}}$ & $1.83^{\mathrm{a}}$ & 0.13 \\
Papillae length, cm & $1.53^{\mathrm{bc}}$ & $1.95^{\mathrm{a}}$ & $1.45^{\mathrm{c}}$ & $1.71^{\mathrm{b}}$ & 0.10 \\
Papillae width, cm & $0.78^{\mathrm{bc}}$ & $1.11^{\mathrm{a}}$ & $0.70^{\mathrm{c}}$ & $0.92^{\mathrm{b}}$ & 0.08 \\
Papillae concentration, number/cm ${ }^{2}$ & $74^{\mathrm{b}}$ & $88^{\mathrm{a}}$ & $70^{\mathrm{b}}$ & $91^{\mathrm{a}}$ & 4.00 \\
\hline
\end{tabular}

${ }^{\mathrm{a}-\mathrm{c} W i t h i n ~ r o w s, ~ m e a n s ~ w i t h ~ d i f f e r e n t ~ s u p e r s c r i p t ~ l e t t e r s ~ a r e ~ s i g n i f i c a n t l y ~ d i f f e r e n t ~}(P<0.05)$.

${ }^{1}$ Six male calves on each calf starter diet were randomly selected and slaughtered at d 70 of age.

${ }^{2}$ Pelleted starter diets containing equal amount of starch (25\% of feed DM) from barley, corn, oats, and wheat were fed to calves.

Table 6. Average nutrients intake and total tract apparent digestibilities in Holstein calves ${ }^{1}$ fed calf starter diets containing barley $(n=6)$, corn $(n=6)$, oats $(n=6)$, and wheat $(n=6)$

\begin{tabular}{|c|c|c|c|c|c|}
\hline \multirow[b]{2}{*}{ Parameter, ${ }^{2} \mathrm{~g} / \mathrm{d}$} & \multicolumn{4}{|c|}{ Diet $^{3}$} & \multirow[b]{2}{*}{ SEM } \\
\hline & Barley & Corn & Oat & Wheat & \\
\hline \multicolumn{6}{|l|}{$\mathrm{DM}$} \\
\hline Intake & $2,325.48^{\mathrm{b}}$ & $2,795.22^{\mathrm{a}}$ & $2,245.67^{\mathrm{b}}$ & $2,734.17^{\mathrm{a}}$ & 120.0 \\
\hline Intake, $\%$ of BW & 2.817 & 2.798 & 2.789 & 2.840 & 0.33 \\
\hline Feces & $669.74^{\mathrm{b}}$ & $909.06^{\mathrm{a}}$ & $625.91^{\mathrm{b}}$ & $781.97^{\mathrm{a}}$ & 35.00 \\
\hline Digestibility & 0.71 & 0.72 & 0.72 & 0.71 & 0.011 \\
\hline \multicolumn{6}{|l|}{$\mathrm{CP}$} \\
\hline Intake & $476.11^{\mathrm{c}}$ & $649.20^{\mathrm{a}}$ & $450.93^{c}$ & $548.69^{\mathrm{b}}$ & 21.00 \\
\hline Feces & $118.08^{\mathrm{b}}$ & $154.51^{\mathrm{a}}$ & $111.30^{\mathrm{b}}$ & $134.43^{\mathrm{a}}$ & 10.00 \\
\hline Digestibility & 0.75 & 0.76 & 0.75 & 0.76 & 0.010 \\
\hline \multicolumn{6}{|l|}{ NDF } \\
\hline Intake & $924.83^{\mathrm{c}}$ & $1,393.42^{\mathrm{a}}$ & $1,011.71^{\mathrm{c}}$ & $1,125.34^{\mathrm{b}}$ & 88.00 \\
\hline Feces & $527.11^{\mathrm{c}}$ & $822.12^{\mathrm{a}}$ & $584.53^{\mathrm{c}}$ & $672.95^{\mathrm{b}}$ & 28.00 \\
\hline Digestibility & 0.43 & 0.41 & 0.42 & 0.40 & 0.010 \\
\hline \multicolumn{6}{|l|}{ Energy, kcal/d } \\
\hline Intake & $10,831.31^{\mathrm{c}}$ & $15,348.66^{\mathrm{a}}$ & $10,774.27^{\mathrm{c}}$ & $12,679.53^{\mathrm{b}}$ & 55.00 \\
\hline Feces & $2,944.48^{\mathrm{c}}$ & $4,435.76^{\mathrm{a}}$ & $2,893.63^{\mathrm{c}}$ & $3,653.14^{b}$ & 29.00 \\
\hline Digestibility & 0.72 & 0.71 & 0.73 & 0.71 & 0.020 \\
\hline \multicolumn{6}{|l|}{ Starch } \\
\hline Intake & $414.58^{\mathrm{c}}$ & $568.32^{\mathrm{a}}$ & $383.16^{\mathrm{c}}$ & $464.79^{\mathrm{b}}$ & 18.00 \\
\hline Feces & $44.77^{\mathrm{a}}$ & $58.83^{\mathrm{b}}$ & $49.04^{\mathrm{a}}$ & $58.35^{\mathrm{b}}$ & 3.50 \\
\hline Digestibility & 0.89 & 0.89 & 0.87 & 0.87 & 0.028 \\
\hline \multicolumn{6}{|l|}{ Calcium } \\
\hline Intake & $20.26^{\mathrm{b}}$ & $27.94^{\mathrm{a}}$ & $18.58^{\mathrm{b}}$ & $25.22^{\mathrm{a}}$ & 1.20 \\
\hline Feces & 6.28 & 7.54 & 5.39 & 7.06 & 0.99 \\
\hline Digestibility & 0.69 & 0.73 & 0.71 & 0.72 & 0.15 \\
\hline \multicolumn{6}{|l|}{ Phosphorus } \\
\hline Intake & $10.50^{\mathrm{b}}$ & $15.09^{\mathrm{a}}$ & $10.08^{\mathrm{b}}$ & $13.36^{\mathrm{a}}$ & 0.80 \\
\hline Feces & 6.99 & 8.77 & 7.83 & 9.11 & 0.61 \\
\hline Digestibility & $0.33^{b}$ & $0.42^{\mathrm{a}}$ & $0.22^{\mathrm{c}}$ & $0.31^{\mathrm{b}}$ & 0.020 \\
\hline
\end{tabular}

${ }^{\mathrm{a}-\mathrm{c}}$ Within rows, means with different superscript letters are significantly different $(P<0.05)$.

${ }^{1}$ Six female calves on each calf starter diet were randomly selected and moved to individual metabolic cages at $\mathrm{d} 63$ of age.

${ }^{2}$ Nutrient intake and apparent total tract digestibility were measured between $\mathrm{d} 77$ and 84 of age

${ }^{3}$ Pelleted starter diets containing equal amount of starch (25\% of feed DM) from barley, corn, oats, and wheat were fed to calves. 
Table 7. Nitrogen utilization in Holstein calves ${ }^{1}$ fed calf starter diets containing barley $(\mathrm{n}=6)$, corn $(\mathrm{n}=6)$, oats $(\mathrm{n}=6)$, and wheat $(\mathrm{n}=$ 6)

\begin{tabular}{lcrrrr}
\hline & \multicolumn{5}{c}{ Diet $^{3}$} \\
\cline { 2 - 5 } Parameter, ${ }^{2}$ g/d & Barley & Corn & Oat & Wheat & SEM \\
\hline N Intake & $76.18^{\mathrm{c}}$ & $103.87^{\mathrm{a}}$ & $72.15^{\mathrm{c}}$ & $87.79^{\mathrm{b}}$ & 3.60 \\
Fecal N & $18.89^{\mathrm{b}}$ & $24.72^{\mathrm{a}}$ & $17.81^{\mathrm{b}}$ & $21.51^{\mathrm{a}}$ & 1.20 \\
Urinary N & $32.00^{\mathrm{b}}$ & $37.00^{\mathrm{a}}$ & $28.00^{\mathrm{c}}$ & $32.00^{\mathrm{b}}$ & 1.90 \\
N Balance & $25.29^{\mathrm{c}}$ & $42.15^{\mathrm{a}}$ & $26.35^{\mathrm{c}}$ & $34.28^{\mathrm{b}}$ & 2.10 \\
N Balance, \% of DNI $^{4}$ & $44.14^{\mathrm{c}}$ & $53.25^{\mathrm{a}}$ & $48.49^{\mathrm{b}}$ & $51.71^{\mathrm{a}}$ & 1.80 \\
\hline
\end{tabular}

${ }^{\mathrm{a}-\mathrm{c}}$ Within rows, means with different superscript letters are significantly different $(P<0.05)$.

${ }^{1}$ Six female calves on each calf starter diet were randomly selected and moved to individual metabolic cages at d 63 of age.

${ }^{2}$ Nitrogen utilization was measured between $d 77$ and 84 of age.

${ }^{3}$ Pelleted starter diets containing equal amount of starch $(25 \%$ of feed DM) from barley, corn, oats, and wheat were fed to calves.

${ }^{4}$ Digestible $\mathrm{N}$ intake.

delayed ruminal epithelial development in neonatal calves (Baldwin et al., 2004). Average daily starch intake at d 35 in calves fed barley, corn, oat, and wheat diets was similar (Khan et al., 2007a); thus, the differences in ruminal $\mathrm{pH}$ among calves may only be attributed to the starch fermentation pattern. Furthermore, ruminal $\mathrm{pH}$ in calves is a function of the rate at which VFA and ammonia build up and the rate of their absorption into circulation or utilization by microbes (Quigley, 1996; Baldwin et al., 2004). Greater ruminal $\mathrm{pH}$ in calves on the corn diet compared with those fed the barley diet may be attributed to more solid feed and protein consumption, greater ruminal protein degradation, and thus, greater ruminal ammonia. Similar to the present results, Khan et al. (2007b) explained that the greater protein intake and its ruminal degradation resulted in greater concentrations of ruminal ammonia and $\mathrm{pH}$ in calves. Aldrich et al. (1993) reported a tendency for decreasing rumen $\mathrm{NH}_{3}$ concentrations as starch degradability increased. Higher $\mathrm{pH}$ at $\mathrm{d} 50$ and 70 of age in calves on the oat diet compared with those on the barley diet may be ascribed to a slower rate of starch fermentation and thus lower ruminal VFA concentration in the former. Solid feed intake, starch consumption, and ruminal ammonia concentrations at weaning and during the postweaning period were similar in calves fed barley and oat diets (Khan et al., 2007a). Greater ruminal ammonia at d 35, 50, and 70 of age in calves on corn and wheat diets compared with those on barley and oat diets may be attributed to greater protein intake and its degradation by ruminal microbes.

Greater ruminal total VFA concentrations at d 35, 50 , and 70 of age in calves on the corn and wheat diets compared with barley and oat diets may be ascribed to significantly greater solid feed and starch consumption during preweaning and postweaning periods, as presented in the companion article (Khan et al., 2007a) and probably better fermentation of organic matter by ruminal microbes (Owen et al., 1967; Baldwin et al., 2004). Lesser concentrations of ruminal total and individual VFA at d 50 compared with $d 35$ may be because of an increased capacity of ruminal epithelium to absorb VFA (Sutton et al., 1963; Lane et al., 2000). Ruminal VFA concentration in calves is the function of a differential between rates of organic matter fermentation to VFA and their absorption into circulation. Greater metabolic activity of rumen epithelial and increased rumen absorptive area in calves with their advancing age was attributed to greater OM fermentation and greater concentrations of VFA in the rumen (Owen et al., 1967; Lesmeister and Heinrichs, 2004). In present study, blood BHBA concentrations were increased in older calves, possibly indicating greater rumen epithelial metabolism and capacity to absorb VFA (Baldwin et al., 2004).

Greater full and empty forestomach weight and RWT in calves on corn and wheat diets compared with the barley and oat diets may be ascribed to greater physical stimuli because of increased consumption of solid feed. Greater ruminal PL, PW, and papillae concentration in calves on the corn and wheat diets may be attributed to better chemical stimuli by greater concentrations of ruminal VFA. Following the initiation of solid feed intake by the calves and the subsequent establishment of the ruminal fermentation, the rumen undergoes both physical and metabolic development (Baldwin et al., 2004). Physical development of the rumen can be further partitioned into 2 aspects: increases in rumen mass and growth of papillae. Early research indicated that physical stimulation by feed in the rumen could account for measurable increases in both rumen weight and musculature development (Coverdale et al., 2004; Suárez et al., 2006b). The presence of physical bulk alone does not, however, promote papillary development (Hamada et al., 1976; Lesmeister and Heinrichs, 2004). Thus, for normal development of the ruminal epithelium to progress, a viable ruminal fermentation must be established, suggesting that there is a requirement for the presence of short-chain fatty acids (especially propionate and butyrate) in the ruminal lumen to promote normal papillary development (Sander et al., 1959). It may be suggested that the early initiation and greater consumption of starter and MGH have provided greater chemical and physical stimuli, respectively, and thereby resulted in greater weights of forestomach, RTW, PL, PW, and papillae concentration in calves on the corn and wheat diets compared with those fed barley and oat diets. 
One of the most defining characteristics of a fully developed functioning foregut in a fed, nonpregnant, nonlactating animal is ruminal production of ketones (Baldwin et al., 2004). Blood BHBA concentration, which is an important indicator of metabolic activity in ruminal epithelial (Lane et al., 2000), was also greater at $\mathrm{d} 30,50$, and 70 in calves on corn and wheat diets compared with those on barley and oat diets. Quigley (1996) has demonstrated that in young calves, the rumen epithelium has the capacity to absorb and metabolize VFA from an early age. Consequently, in rearing calves, increased rumen VFA concentrations are associated with high plasma BHBA concentrations. Much lower blood glucose concentrations and greater BUN presented in the companion article (Khan et al., 2007a) and significantly greater blood BHBA concentration in calves on corn and wheat diets compared with those fed barley and oat diets may be attributed to greater solid feed consumption, better ruminal fermentation, and thus more reliance on its end products to derive energy needs.

Higher daily nutrients (CP, NDF, starch, $\mathrm{Ca}$, and $\mathrm{P}$ ) and energy consumption in calves on the corn and wheat diets may be attributed greater ruminal physical capacity to accommodate more feed bulk and better ruminal metabolic ability to ferment OM. Body weight was also greater in calves on corn and wheat diets than those on the barley and oat diets. Average daily DM as a percentage of BW was similar in calves fed diets containing starch from different sources (Table 6). Greater demands of nutrients because of greater BW and a better functional rumen resulted in greater nutrient intake by calves on the corn and wheat diets. Furthermore, low consumption of nutrients in calves fed barley diet than in those fed corn and wheat diets may be related to the low ruminal $\mathrm{pH}$ observed in this experiment, because acidosis generally depresses the DMI (Owens et al., 1998; Huntington et al., 2006). In this experiment, NDF was higher in the oat diet, which probably depressed DMI in calves. Intake of DM is inversely related to digestibility in cattle (Sarwar et al., 1991). However, in the present study, similar total tract apparent nutrient (DM, CP, starch, NDF, and Ca) digestibilities were noticed among calves fed barley, corn, oat, and wheat diets. Greater intake in the corn and wheat diets was expected to reduce the digestibility due to faster rate of passage. Greater phosphorus digestibility in calves on the corn diet compared with the other diets is in line with previous findings, which suggested that feeding more digestible starch sources decrease $\mathrm{P}$ excretion in cattle (Nelson et al., 1968; Guyton et al., 2003). Although the mechanism for decreased P excretion with more ruminally available starch sources is unclear, one possible explanation is that availability of dietary starch may affect ruminal phytase activity. Approximately 65 to $70 \%$ of the total P in cereal grains is organically bound in phytate $\mathrm{P}$ (Morse et al., 1992). Phytate $\mathrm{P}$ is more available to ruminants than to nonruminants, because ruminal microorganisms possess the enzyme phytase (Yanke et al., 1998). Phytase breaks the phosphate groups from the inositol ring, making the $\mathrm{P}$ more available for absorption in the small intestine (Morse et al., 1992; Yanke et al., 1998). In the present study, differences in apparent $\mathrm{P}$ digestibility among calves fed different starch sources may be ascribed to variation in ruminal capacity to digest starch and OM.

Greater daily $\mathrm{N}$ intake in calves on the corn diet compared with those on the wheat, barley, and oat diets was the function of greater consumption of both starter and hay. Differences in fecal $\mathrm{N}$ excretion among calves fed different starch sources may be attributed to the variation in protein consumption because apparent total tract CP digestibility was similar among calves. Greater urinary N excretion in calves on corn and wheat diets compared with those fed barley and oat diets mimic their BUN concentration. The BUN at wk 10 and 12 of age was greater in calves on the corn and wheat diets than in those fed the barley and oat diets (Khan et al., 2007a). Ruminal ammonia $\mathrm{N}$ that exceeds the fixation capacity of ruminal microbes is absorbed into portal vein circulation and converted to urea in the liver. Blood urea nitrogen is either recycled to the rumen through the ruminal wall and saliva or excreted from the body in urine. Urea recycling is generally greater in protein-deficient diets in cattle and related to ruminal ammonia level (Khan et al., 2006). In the present study, ruminal ammonia was greater in calves on the corn and wheat diets because of greater protein consumption and probably greater degradation; thus, excessive BUN was excreted through urine (Lohakare et al., 2006). It is important to note that a greater concentration of BUN is also an index of renal dysfunction; however, in our study (Khan et al., 2007a), the creatinine concentration in the calves was in the normal range and did not differ among treatments. Greater $\mathrm{N}$ intake and probably greater $\mathrm{N}$ capture by ruminal microbes resulted in greater $\mathrm{N}$ retention in calves fed corn and wheat diets than in those fed oat and barley diets. Ruminal microbes, particularly bacteria, use ruminal ammonia $\mathrm{N}$ along with organic acids to synthesis amino acids for their growth. Regular flushing of these microbes from rumen and their subsequent digestion in small intestine provide amino acids to cattle for maintenance, growth, and lactation. Greater BW gain observed in calves on the corn and wheat diets (Khan et al., 2007a) can be attributed to greater availability of amino acids and other nutrients. 


\section{CONCLUSIONS}

Corn and wheat diets resulted in greater concentrations of ruminal ammonia, acetate, propionate, and butyrate in calves. The calves on these also had greater BHBA, and heavier, thicker and more-developed rumens, with longer and more-functional papillae. Greater solid feed consumption and greater $\mathrm{N}$ utilization and retention were also noted in calves on the corn and wheat diets.

\section{ACKNOWLEDGMENTS}

This study was conducted as a part of the postdoctoral research project funded by the National Institute of Animal Science, Rural Development Administration, South Korea.

\section{REFERENCES}

Aldrich, J. M., L. D. Muller, G. A. Varga, and L. C. Griel Jr. 1993. Nonstructural carbohydrate and protein effects on rumen fermentation, nutrient flow, and performance of dairy cows. J. Dairy Sci. 76:1091-1105.

AOAC. 1990. Official Methods of Analysis. 15th ed. Association of Official Analytical Chemists, Arlington, VA.

Baldwin, R. L., VI, K. R. McLeod, J. L. Klotz, and R. N. Heitmann. 2004. Rumen development, intestinal growth and hepatic metabolism in the pre- and post-weaning ruminant. J. Dairy Sci. 87 (E Suppl.):E55-E65.

Broderick, G. A., and J. H. Kang. 1980. Automated simultaneous determination of ammonia and total amino acids in ruminal fluid and in vitro media. J. Dairy Sci. 63:64-75.

Coverdale, J. A., H. D. Tyler, J. D. Quigley III, and J. A. Brumm. 2004. Effect of various levels of forage and form of diet on rumen development and growth in calves. J. Dairy Sci. 87:2554-2562.

Guyton, A. D., J. M. McKinney, and K. F. Knowlton. 2003. The effect of steam-flaked or dry ground corn and supplemental phytic acid on phosphorus partitioning and ruminal phytase activity in lactating cows. J. Dairy Sci. 86:3972-3982.

Hall, M. B. 2001. Neutral detergent-soluble carbohydrates nutritional relevance and analysis (A laboratory manual). Pages V-1 to V-9 in Univ. Florida Bulletin 339, Dept. Anim. Sci., Inst. Food Agric. Sci., Gainesville, FL.

Hamada, T., S. Maeda, and K. Kameoka. 1976. Factors influencing growth of rumen, liver, and other organs in kids weaned from milk replacers to solid foods. J. Dairy Sci. 59:1110-1118.

Harrison, H. N., R. G. Warner, E. G. Sander, and J. K. Loosli. 1960. Changes in the tissue and volume of the stomachs of calves following the removal of dry feed or consumption of inert bulk. J. Dairy Sci. 43:1301-1312.

Huntington, G. B. 1997. Starch utilization by ruminants: From basics to the bunk. J. Anim. Sci. 75:852-867.

Huntington, G. B., D. L. Harmon, and C. J. Richards. 2006. Sites, rates, and limits of starch digestion and glucose metabolism in growing cattle. J. Anim. Sci. 84(E Suppl.):E14-E24.

Khan, M. A., Z. Iqbal, M. Sarwar, M. Nisa, M. S. Khan, H. J. Lee, W. S. Lee, H. S. Kim, and K. S. Ki. 2006. Urea treated corncobs ensiled with or without additives for buffaloes: Ruminal characteristics, digestibility and nitrogen metabolism. Asian-australas. J. Anim. Sci. 19:705-712.

Khan, M. A., H. J. Lee, W. S. Lee, H. S. Kim, S. B. Kim, K. S. Ki, S. J. Park, J. K. Ha, and Y. J. Choi. 2007a. Starch source evaluation in calf starter: I. Feed consumption, body weight gain, structural growth, and blood metabolites in Holstein calves. J. Dairy Sci. 90:5259-5268.
Khan, M. A., H. J. Lee, W. S. Lee, H. S. Kim, S. B. Kim, K. S. Ki, J. K. Ha, H. G. Lee, and Y. J. Choi. 2007b. Pre- and post-weaning performance of Holstein female calves fed milk through stepdown and conventional methods. J. Dairy Sci. 90:876-885.

Khan, M. A., H. J. Lee, W. S. Lee, H. S. Kim, K. S. Ki, T. Y. Hur, G. H. Suh, S. J. Knag, and Y. J. Choi. 2007c. Structural growth, rumen development, metabolic and immune response of Holstein male calves fed milk through step-down and conventional methods. J. Dairy Sci. 90:3376-3387.

Kotarski, S. F., R. D. Waniska, and K. K. Thurn. 1992. Starch hydrolysis by the rumen microflora. J. Nutr. 122:178-190.

Lane, M. A., R. L. Baldwin, and B. W. Jesse. 2000. Sheep rumen metabolic development in response to age and dietary treatments. J. Anim. Sci. 78:1990-1996.

Lesmeister, K. E., and A. J. Heinrichs. 2004. Effects of corn processing on growth characteristics, rumen development and rumen parameters in neonatal dairy calves. J. Dairy Sci. 87:3439-3450.

Lesmeister, K. E., P. R. Tozer, and A. J. Heinrichs. 2004. Development and analysis of a rumen tissue sampling procedure. J. Dairy Sci. 87:1336-1344.

Lohakare, J. D. A. K. Pattanaik, and S. A. Khan. 2006. Effect of dietary protein levels on the performance, nutrient balances, metabolic profile and thyroid hormones of crossbred calves. Asianaustralas. J. Anim. Sci. 19:1588-1596.

Morse, D., H. Head, C. J. Wilcox, H. H. V. Horn, C. D. Hissem, and B. Harris Jr. 1992. Effects of concentration of dietary phosphorous on amount and route of excretion. J. Dairy Sci. 75:3039-3049.

Nelson, T. S., L. W. Ferrara, and N. L. Storer. 1968. Phytate phosphorus content of feed ingredients derived from plants. Poult. Sci. 47:1372-1374.

Nocek, J. E., C. W. Heald, and C. E. Polan. 1984. Influence of ration physical form and nitrogen availability on ruminal morphology of growing bull calves. J. Dairy Sci. 67:334-343.

Nocek, J. E., and S. Tamminga. 1991. Site of digestion of starch in the gastrointestinal tract of dairy cows and its effect on milk yield and composition. J. Dairy Sci. 74:3598-3629.

Offner, A., A. Bach, and D. Sauvant. 2003. Quantitative review of in situ starch degradation in the rumen. Anim. Feed Sci. Technol. 106:81-93.

Owen, F. G., D. W. Kellogg, and W. T. Howard. 1967. Effect of molasses in normal- and high-grain rations on utilization of nutrients for lactation. J. Dairy Sci. 50:1120-1125.

Owens, F. N., D. S. Secrist, W. J. Hill, and D. R. Gill. 1998. Acidosis in cattle: A review. J. Anim. Sci. 76:275-286.

Philippeau, C., F. Le Deschault de Monredon, and B. Michalet-Doreau. 1999. Relationship between ruminal starch degradation and the physical characteristics of corn grain. J. Anim. Sci. 77:238243.

Quigley, J. D., III. 1996. Influence of weaning method on growth intake and selected blood metabolites in Jersey calves. J. Dairy Sci. 79:2255-2260.

Sander, E. G., H. N. Warner, H. N. Harrison, and J. K. Loosli. 1959. The stimulatory effect of sodium butyrate and sodium propionate on the development of rumen mucosa in the young calf. J. Dairy Sci. 42:1600-1605.

Sarwar, M., J. L. Firkins, and M. L. Eastridge. 1991. Effect of replacing neutral detergent fibre of forage with soy hulls and corn gluten feed for dairy heifers. J. Dairy Sci. 74:1006.

SAS Institute. 1994. SAS User's Guide. Statistics. Version 6.11 ed. SAS Institute Inc., Cary, NC.

Stobo, I. J. F., J. H. B. Roy, and H. J. Gaston. 1966. Rumen development in the calf. 1 . The effect of diets containing different proportions of concentrates to hay on rumen development. Br. J. Nutr. 20:171-188.

Suárez, B. J., C. G. Van Reenen, G. Beldman, J. van Delen, J. Dijkstra, and W. J. J. Gerrits. 2006a. Effects of supplementing concentrates differing in carbohydrate composition in veal calf diets: I. Animal performance and rumen fermentation characteristics. J. Dairy Sci. 89:4365-4375.

Suárez, B. J., C. G. Van Reenen, W. J. J. Gerrits, N. Stockhofe, A. M. van Vuuren, and J. Dijkstra. 2006b. Effects of supplementing 
concentrates differing in carbohydrate composition in veal calf diets: II. Rumen development. J. Dairy Sci. 89:4376-4386.

Sutton, J. D., A. D. McGilliard, and N. L. Jacobson. 1963. Functional development of rumen mucosa. I. Absorptive ability. J. Dairy Sci. 46:426-436.

Svihus, B., A. K. Uhlen, and O. M. Harstad. 2005. Effect of starch granule structure, associated components and processing on nutritive value of cereal starch: A review. Anim. Feed Sci. Technol. 122:303-320.

Swan, C. G., J. G. P. Bowman, J. M. Martin, and M. J. Giroux. 2006 Increased puroindoline levels slow ruminal digestion of wheat (Triticum aestivum L.) starch by cattle. J. Anim. Sci. 84:641-650.

Tamate, H., A. D. McGilliard, N. L. Jacobson, and R. Getty. 1962. Effect of various dietaries on the anatomical development of the stomach in the calf. J. Dairy Sci. 45:408-420.
Theurer, C. B., O. Lozano, A. Alio, A. Delgado-Elorduy, M. Sadik, J. T. Huber, and R. A. Zinn. 1999. Steam-processed corn and sorghum grain flaked at differenct densities alter ruminal, small-intestinal, and total tract digestibility of starch by steers. J. Anim. Sci. 77:2824-2831.

Van Soest, P. J., J. B. Robertson, and B. A. Lewis. 1991. Methods for dietary fiber and nonstarch polysaccharides in relation to animal nutrition. J. Dairy Sci. 74:3583-3597.

Williamson, D. H., and J. Mellanby. 1974. D-(-)-3-Hydroxybutyrate. Pages 1836-1840 in Methods of Enzymatic Analysis. Vol. 4 H. U. Bergmeyer, ed. Acad. Press, London, UK.

Yanke, L. J., H. D. Bae, L. B. Selinger, and K. J. Cheng. 1998. Phytase activity of anaerobic ruminal bacteria. Microbiology 144:15651573. 